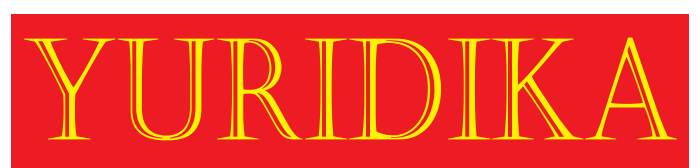

Volume 33 No. 2, Mei 2018

DOI: $10.20473 /$ ydk.v33i2.8099

Fakultas Hukum Universitas Airlangga, Jalan Dharmawangsa Dalam Selatan

Surabaya, 60286 Indonesia, +6231-5023151/5023252

Fax+6231-5020454, E-mail: yuridika@fh.unair.ac.id Yuridika (ISSN: 0215-840X | e-ISSN: 2528-3103)

\begin{tabular}{lll}
\hline FAKULTAS HUKUM UNIVERSITAS AIRLANGGA & commons Attribution-NonCommercial-ShareAlike 4.0 \\
International License.
\end{tabular}

Article history: Submitted 4 February 2018; Accepted 5 March 2018; Available Online 1 May 2018

\title{
PERPLEXING JURISDICTION RATIONE PERSONAE AND MATERIAE OF RWANDAN COMMERCIAL COURTS: TRADER AND COMMERCIAL ACTIVITY
}

\author{
Joel Niyobuhungiro \\ joeljoe2020@gmail.com \\ Universitas Airlangga
}

\begin{abstract}
The creation of commercial courts, as specialized courts, has been and still is at the root of commercial development that contributes to economic growth of a country. Like any court, for commercial court to adjudicate a case, a number of elements determining the court competence must be examined by the court seized. Jurisdiction ratione materiae and jurisdiction ratione personae, inter alia, are the determining factors of the competence of commercial courts. However, it can be difficult, in some cases, to ascertain court competence in case the law establishing those courts has not clearly delineated, for example, matters over which courts shall have jurisdiction. In Rwanda, The Law No. 06/2012/OL of 14/09/2012 determining the organization, functioning and jurisdiction of commercial courts, which repealed the Law No 59/2007 of 16/12/2007, neither does it define a commercial activity nor does it define a trader. This creates big perplexity in determining commercial courts competence insofar as jurisdiction ratione materiae and ratione personae are concerned. Commercial activities are neither defined nor enumerated in Rwanda laws. Rwandan commercial courts judges have tried to unravel that perplexity and tried to solve this problem in their judgements. However, it will be submitted that challenges posed by lack of clear definition of trader and commercial activity or at least a list of commercial activities, calls for a clear stand of the legislator as far as jurisdiction ratione materiae and personae of commercial courts is concerned.
\end{abstract}

\begin{abstract}
Abstrak
Pembentukan peradilan niaga sebagai pengadilan khusus, telah menjadi dasar yang berkontribusi terhadap pembangunan ekonomi sebuah negara.Sama dengan pengadilan lainnya, saat pengadilan niaga memeriksa sebuah kasus, elemen yang menentukan kompetensi harus diperhatikan oleh pengadilan niaga. Prinsip Jurisdiction Ratione Materiae dan Jurisdiction Personae, adalah elemen utama yang menentukan kompetensi pengadilan niaga. Namun, menentukan kompetensi pengadilan terkadang menjadi sulit untuk beberapa kasus, khususnya bila peraturan perundang-undangan tidak secara jelas mengaturnya. Di Rwanda, berdasarkan Law No. 06/2012/OL of 14/09/2012 Tentang Organisasi, Fungsi dan Yurisdiksi Pengadilan Niaga, yang merupakan amandemen dari Law No. 59/2007 of 16/12/2007, belum secara tegas mengatur definisi aktifitas komersial (commercial activity) maupun pebisnis (trader). Tidak adanya definisi yang tegas ini menimbulkan permasalahan dalam menentukan kompetensi pengadilan niaga yang berkaitan dengan yurisdiksi ratione materiae dan personae. Aktifitas komersial (commercial activities)tidak didefinisikan dan dijelaskan dalam hukum Rwanda. Para hakim pengadilan niaga di Rwanda telah mencoba mencari solusi permasalahan ini. Namun, studi kasus dalam artikel ini menunjukkan bahwa ketidakjelasan definisi apa itu aktifitas komersial dan siapa itu pebisnis, membuat diperlukannya pembentukan aturan hukum baru oleh legislator berkaitan dengan yurisdiksi ratione materiae dan personae dari pengadilan niaga Rwanda. Kata Kunci: Yurisdiksi Ratione Pesonae; Yurisdiksi Ratione Materiae; Pebisnis; Aktifitas Komersial.
\end{abstract}




\section{Introduction}

All over the world, there exist courts systems whose major purpose is settling the disputes that may arise between persons (both legal and natural persons). In Country Court system, courts may be divided into two major types: ordinary courts and specialized courts. The latter deal with specific matters or deal with specific individuals. The issue of ordinary and specialized courts can also be observed in private law whereby it is not strange to find courts that deal with civil cases in general and specialized courts that deal with various matters like commercial or labour related disputes. In any case, the creation of specialized courts is driven by the fact that there are some disputes that arise from areas that need a special expertise for the judge to deal with such cases.

Today, there is a trend of putting in place specialized commercial courts or commercial divisions in ordinary courts. This was also noted by the World Bank in its doing business report of 2005 where it states that the popular reform feature over last five years has been the introduction of commercial courts or commercial divisions with countries court systems. ${ }^{1}$ These courts adjudicate disputes relating to commercial activities and involving traders. Understandably, this should not be taken for granted; there is a rationale behind the establishment of these specialized commercial courts. The relevancy of commercial courts in the modern judiciary in recent years and even before, has been the development of commercial development that is perceived to be vital to the economic growth of any nation. ${ }^{2}$

Rwanda, a country that has pledged to fast track the development of business, has not lagged behind. It was not until 2007 that commercial courts were first introduced by the organic law No. 59/2007 of 16/12/2007 establishing the commercial courts and determining their organization, functioning and jurisdiction. It put in place commercial courts of two levels namely Commercial High Court and Commercial

\footnotetext{
${ }^{1}$ World Bank, 'Doing Business Report' (2009).[52].

${ }^{2}$ B. J. Odoki, 'The Relevancy of Commercial Courts to Modern Judiciary', A Case Study From Uganda: Chief Justies Forum Conference (Republic of Uganda 2010) <http://www.venice. coe.int/SACJF/2010_08_RSA_Johannesburg/Uganda.pdf $>$.[9].
} 
Courts whose jurisdiction deals with all disputes relating to commercial matters and with at the forefront disputes arising from commercial contracts or commercial activities between persons (emphasis added) or business entities. In 2012 the law enacted in 2007 was repealed and replaced by a new law. Like its predecessor, the new law provided that commercial matters shall mean commercial, financial, fiscal and other related matters, with at the forefront disputes arising from commercial contracts or commercial activities between persons or business entities. ${ }^{3}$

Interestingly, neither the organic law No. 59/2007 of 16/12/2007 establishing the commercial courts and determining their organization, functioning and jurisdiction, nor the Law No. 06/2012/OL of 14/09/2012 determining the organization, functioning and jurisdiction of commercial courts, does define what a commercial activity is and who a trader is while these are determining factors with regard to both jurisdiction ratione materiae and personae of commercial courts. This is a significant observation that requires reflection especially as even before these commercial courts these issues are not easily dealt with as it can be seen in case laws. ${ }^{4}$ Thus, there is a need to ascertain these issues by analysing case laws.

This article analyses what a trader and commercial acts denote in regard to the jurisdiction ratione materiae and jurisdiction ratione personae of Rwandan commercial courts. As methodology in analysing these issues, the research will use case analysis approach by analysing case laws especially in Rwanda. Moreover, the research will take look at French jurisdiction to analyse and compare how judges have dealt with these sophisticated cases. The rationale of this comparison with French cases related to the issue at hand is that France is civil law country and has impact on Rwandan judicial system, courts structure and laws. Rwanda emulates France in many legal related aspects. In addition, both French laws and Rwandan

\footnotetext{
${ }^{3}$ Organic Law No. 06/2012/OL of 14/09/2012 determining the organization, functioning and jurisdiction of commercial courts, in $O . G$, No.45 of 05/11/2012, article 2 (a).

${ }^{4}$ See Supreme Court, Kigali, 22/02/2013, N. J.B v. FINA BANK Ltd, Judgment no RCOM A $0122 / 11 / \mathrm{CS}$ (Hereinafter referred to as 'FINABANK Case') Para 12-15, See also Commercial High Court, Kigali, 29/07/2011, AGRODEV Sarl v. R.V, Judgment noN ${ }^{\circ}$ R.COM A 0361/10/HCC (Hereinafter referred to as 'AGRODEV Sarl Case'), Para 6-7.
} 
laws do not define a trader and commercial activity. French judges encountered this challenge long time ago whereas in Rwanda it is a new challenge and Rwandan judges refer to French decisions when necessary for inspiration.

This analysis is important because the law establishing commercial courts does not delineate those concepts yet they are cornerstone in determination of commercial courts' competence. It will help knowing if one is engaged in commercial activity which submits them to commercial courts. It aims at exposing these challenges faced by judges and depicting, through cases, how judges have tried to overcome them. It also calls for a clear stand of the legislator as far as jurisdiction ratione materiae and personae of Rwandan commercial courts are concerned.

\section{Definitions and Meaning of Key Concepts}

For a court to determine whether it has a jurisdiction, synonymously referred to as a court competence, i.e. the authority given by law to a court to try cases and rule on legal matters over certain types of legal claims and/or within a particular geographic area, ${ }^{5}$ a number of crucial elements have to be observed: jurisdiction ratione personae, jurisdiction ratione materiae, jurisdiction ratione loci and jurisdictione ratione temporis. For the purpose of this research, the concern is jurisdiction ratione personae and jurisdiction ratione materiae. Moreover, it is important to understand what is meant by a trader and commercial activities.

\section{Jurisdiction Ratione Personae}

Ratione personae is a Latin term which literally means by reason of this person or by reason of the person concerned. ${ }^{6}$ It refers to a court's power to bring a person into its adjudicative process and it is the jurisdiction over a defendant's personal rights, rather than merely over property interests. ${ }^{7}$ Jurisdiction ratione personae is

\footnotetext{
${ }^{5}$ Dutch Civil Law, 'Jurisdiction'(dutchcivillaw) < http://www.dutchcivillaw.com/jurisdiction/ nationaljuris.htm> accessed 22 December 2017.

${ }^{6}$ US. Legal, 'Ratione Personae' (US. Legal, 2016) < http://definitions.uslegal.com/r/rationepersonae $>$ accessed 22 December 2017.

${ }^{7} \mathrm{ibid}$.
} 
the right of courts classified in a certain category of jurisdiction to take cognizance of a suit to the exclusion of other courts of the same category and this competence is generally determined by the domicile or residence of the defendant. ${ }^{8}$

\section{Jurisdiction or Competence Ratione Materiae}

Jurisdiction Ratione Materiae otherwise referred to as subject-matter jurisdiction is the object or the amount in dispute. ${ }^{9}$ It is so called because the suits are distributed among different classes of courts on account of the nature of the action. ${ }^{10}$ It is the jurisdiction over the nature of the case and the type of relief sought; the extent to which a court can rule on the conduct of persons or the status of things. ${ }^{11}$ The reasoning behind subject-matter jurisdiction is that the court with the greatest interest in deciding the dispute should be the court that has the opportunity to make a ruling on it. ${ }^{12}$

\section{Trader}

The term "trader" homogeneously used as "merchant" in some legal areas, refers to a person who does trade. In this regard, trade means the business of buying and selling. ${ }^{13}$ In France, traders are those who carry out commercial instruments and who make this their usual profession. ${ }^{14}$

\section{Commercial Activity}

A "commercial activity" means either a regular course of commercial conduct or a particular commercial transaction or act. ${ }^{15}$ The commercial character of an

\footnotetext{
${ }^{8}$ Robert Roberts III, 'Jurisdiction Ratione Materiae et Personae in Louisiana' (1952) 12 Louisiana Law Review <https://digitalcommons.law.lsu.edu/cgi/viewcontent.cgi?article=1933\&contex$\mathrm{t}=$ lalrev $>$.

${ }^{9}$ UNCTAD, Dispute Settlement (Geneva 2003) <www.unctad.org>.[7].

${ }^{10}$ ibid.[3].

${ }^{11}$ US. Legal.Op.Cit.

12 ibid.

${ }^{13}$ P.H. Collin, Dictionary of Law (4th edn, Bloomsbury Publishing 2004) $<$ http://www.academia.edu/14945138/Dictionary_of_Law_-_P_H._Collin_Bloomsbury_Reference_4th_Edition_>.

${ }^{14}$ L. Vogel, Commercial Code of France (legifrance 2006) $<$ https://www.legifrance.gouv.fr/ content/download/1951/13685/version/5/file/Code_32.p>.[L121-1].

${ }^{15}$ US Legal, 'Commercial Activity' (US Legal, 2016) < http://definitions.uslegal.com/c/commercial-activity> accessed 24 December 2017.
} 
activity shall be determined by reference to the nature of the course of conduct or particular transaction or act rather than by reference to its purpose. ${ }^{16}$ According to Personal Information Protection and Electronic Document Act (PIPEDA) "commercial activity" means "any particular transaction, act or conduct or any regular course of conduct that is of a commercial character, including the selling, bartering or leasing of donor, membership or other fundraising lists ". ${ }^{17}$

\section{Jurisdiction Ratione Personae and Jurisdiction Ratione Materiae: Trader and Commercial Activity In France}

French commercial code does not define a commercial activity. Nonetheless; acts amounting to commerciality are enumerated in commercial code. In addition to that, there is a hint of how one can ascertain if a posed act amounts to commerciality as stated in French words "un acte de commerce est un acte ou un fait juridique qui sera soumis aux dispositions du droit commercial en raison de sa nature, de sa forme ou de la qualité de la personne qui le réalise". ${ }^{18}$

Literally, this means that a commercial act is an act or legal fact that shall be subjected to commercial law because of its nature, form or status and quality of its author (person who performs it). For example, purchasing and resale activities or industrial activities inter alia, are commercial activities. ${ }^{19}$ Commercial activities also called instruments are enumerated in the article L110-1\&2 of the French commercial code as follow:

1. All purchases of chattels in order to resell this, either in kind or after having worked and developed this;

2. All purchases of real property in order to resell this, unless the purchaser has acted in order to construct one or more buildings and to sell these en bloc or site-by-site;

3. All intermediate operations for the purchase, subscription or sale of buildings, business or shares of property companies;

\footnotetext{
16 ibid.

${ }^{17}$ Section 2(1) of Personal Information Protection and Electronic Document Act (PIPEDA), $<$ https://www.priv.gc.ca/leg_c/interpretations_03_ca_e.asp $>$.

${ }^{18}$ Droit-Finance, 'Acte de Commmerce' (Droit-Finance) $<$ http://droit-finances.commentcamarche.net/faq/23541-acte-de-commerce-definition> accessed 15 April 2011.

${ }^{19}$ Article L 110-1 and article L110-2 of French commercial code $<$ https://www.legifrance. gouv.fr/telecharger_pdf.do?cidTexte=LEGITEXT000005634379>.
} 
4. All chattels rental undertakings;

5. All manufacturing, commission and land or water transport undertakings;

6. All supply, agency, business office, auction house and public entertainment undertakings;

7. All exchange, banking or brokerage operations;

8. All public banking operations;

9. All obligations between dealers, merchants and bankers;

10. Bills of exchange between all persons.

In addition to above mentioned commercial acts, article L110-2 adds the following:

1. All construction undertakings and all purchases, sales and resale of ships for inland and foreign-going navigation;

2. All sea shipments;

3. All purchases and sales of ship's tackle, apparatus and foodstuffs;

4. All chartering or chartering and bottomry loans;

5. All insurances and other contracts relating to maritime trade;

6. All agreements and conventions on crew wages and rents;

7. All engagements of seamen for the service of commercial ships.

Subject-matter competence of commercial courts, can be determined on basis such as nature of the transaction, character of the parties etc. For the nature of transaction, commercial courts are competent in all cases involving commercial acts whether or not the parties before the court are technically merchants. ${ }^{20}$ However, certain activities are commercial only if they constitute a course of conduct rather than mere isolated acts. These include, but not limited to, Mining; Manufacturing; Transportation by land, air, and inland waterways, Supplying of gas, water, and the like. ${ }^{21}$ In the subject matter competence based on the character of parties, commercial courts decide all cases involving business transactions in which both parties are traders, irrespective of whether commercial acts listed in the code are involved. ${ }^{22}$

\section{Case Laws Analysis}

It is worth reminding that commercial activities enumerated in French commercial code are not exhaustive, others can be added on if so decided by

${ }^{20}$ P. Herzog dan M. Weser, Project on International Procedure : Civil Procedure in France (springer 2000).

$$
\begin{aligned}
& { }^{21} \text { ibid. } \\
& { }^{22} \text { ibid.[223]. }
\end{aligned}
$$


judge. Since commercial activities are not defined in French commercial code, it is important to ascertain them through case laws. In the case CITADINI vs. FOLLEREAU, the status of trader and the status of commercial activity were discussed. It is a fascinating judgment rendered by court of appeal because it addressed challenges that courts were encountering on the status of some persons vis à vis commercial activities.

CITADINI purchased a taxi from FOLLEREAU but he did not pay the total amount due and he later failed to pay. FOLLEREA sued him in the commercial tribunal. However, the ratione personae and materiae were challenged by CITADINI arguing that he was not trader but rather a craftsman but the court proved otherwise. He appealed before the court of Appeal which reaffirmed the previous decision. CITADINI's motives were that he drove his taxi himself and did not employ anyone; and that his taxi was a working tool for other work. He also added that he was not registered in the registry of commerce. However, FOLLEREAU insisted that CITADINI was a trader because he daily exploited his taxi for essential commercial purpose to earn profit. Finally, the court affirmed that CITADINI was a trader and that he was engaged in commercial activity hence, subject to commercial courts. ${ }^{23}$ The following factors were considered by the court of appeal:

a. The court found that CITADINI had bought the taxi for his commerce;

b. The court found that carrying person, luggage or the merchandises by CITADINI was a principal element for his profession not a secondary one;

c. The court found that the fact of not being registered in registry of commerce did not suffice and did not imply that he was craftsman, but rather trader because he was enjoying a transportation company;

d. The court found that CITADINI was a professional taxi-driver because in Paris, driving required professional aptitudes;

e. The court also found that CITADINI was doing that transport on daily basis, essentially for commercial purpose with the purpose of making profit from it.

The court argued that non-registration in the commercial register could not necessarily mean that the act was not commercial since there was profit from

\footnotetext{
${ }^{23}$ CITADINI - chauffeur de taxi - contre FOLLEREAU frères - vendeurs de voiture (Arrêt de la cour d'Appel d'octobre 1937).
} 
Transport Company. It was for the purpose of his business that CITADINI bought the car. Therefore, CITADINI had no reason to decline the jurisdiction of the Commercial Court. Consequently, the court dismissed the appeal.

Nevertheless, in the case FREUDENRICHvs. JENO, it was found that not every taxi driver is engaged in commercial activity. FREUDENRICH carried JENOT in her taxi. While getting out from taxi, Jenot got injured and seized the commercial tribunal of Nice claiming damages. FREUDENRICH challenged the competence of the court arguing that she was not subjected to commercial court because she was exploiting only her taxi and exercising an artisanal activity not commercial activity. The case was appealed against until Cassation Court that ruled in favour of FREUDENRICH. Cassation Court concluded that the Court of appeal (that had previously tried the case) did not motivate its basis and did not investigate on whether the manual work of FREUDENRICH did not constitute a principal source of her professional revenue which led to inadequate ruling. ${ }^{24}$

According to these two cases, the activity of driving taxi induces a difference in status. The exercise of the activity must be habitual. An isolated act of trade does not give quality of trader. For example, whoever buys a car and sells it remains subject to civil law. However, the habit is not enough because business activity should moreover, be exercised as principal as senior i.e. the main income of the trader. ${ }^{25}$ In the two cases above, the courts have set standards that can help ascertaining if a posed act amounts to commercial activity. The word "daily" used in CITADINI case evokes the habit. The words "essentially commercial" evoke the main activity. ${ }^{26}$ It is necessary to consider whether the act performed constitutes the main element of one's profession or whether it only appears as secondary and if the status of trader assumes the usual realization of main commercial acts.

\footnotetext{
${ }^{24}$ Arrêt de la cour de Cassation du 4 décembre 1968(Madame FREUDENRICH - chauffeur de taxi-contre Madame JENOT - victime).

${ }^{25}$ ibid.

${ }^{26}$ ibid.
} 


\section{Categories of Commercial Activities}

Commercial acts according to various doctrines and French jurisprudence have been put in three categories i.e. commercial activities by nature, commercial activities by object and commercial activities by accessories. ${ }^{27}$

\section{Commercial Acts by Nature}

Commercial acts by nature are synonymously called isolated commercial acts. ${ }^{28}$ The commerciality of these activities gives commercial character to all acts that constitute it as stated in French words: "La commercialité de l'activité confère à chacun des actes qui la composent, le caractère commercial". ${ }^{29}$

Commercial acts by nature or isolated commercial acts, give the person who performs them a status or quality of trader. For example: purchase for resale, brokerage, banking, transport company. ${ }^{30}$ Commercial acts by nature do not necessarily require that a person who exercises them be a trader, they are commercial in nature. Therefore, the persons engaged in those acts shall be subject to commercial courts. ${ }^{31}$

\section{Commercial Acts by Object}

Commercial acts by object are all acts which give the quality of trader to those who perform them. These activities submit those who perform them to the commercial law without these persons being traders. ${ }^{32}$ For example; the person who signs a bill of exchange performs an act of trade, however, this person will not have the status or quality of trader. ${ }^{33}$

\section{Commercial Activities by Accessories}

\footnotetext{
${ }^{27}$ P. Michel, Droit Commercial Commerçants et Fonds de Commerce, Concurrence, et Contrats de Commerce (2nd edn, Dalloz 200AD).[67].

${ }^{28}$ Lextenso, 'Activité Commercial Par Nature' (Lextenso) <athttps://www.lextenso.fr/lextenso/ud/urn:9782275 05 0294-91> accessed 14 April 2017.

${ }^{29}$ Cours Universiataire, 'LEA: Actes de Commerce'(Cours Universiataire) <http://www.coursuniv.fr/cours/licence/langues/licence-lea-droit-commercial-3.html> accessed 6 November 2017.

${ }^{30}$ ibid.

${ }^{31}$ See Supra note 28

${ }^{32}$ See supra note 29

${ }^{33}$ ibid
} 
Commercial activities by accessories are activities which do not give quality of trader but presuppose it. They are accessories because they are attached to other activities which are principle activities. ${ }^{34}$ CITADINI Case previously discussed can be a good example of commercial activities by accessories.

\section{Jurisdiction Ratione Personae and Jurisdiction Ratione Materiae of Rwandan}

\section{Commercial Courts: Trader and Commercial Activity}

Jurisdiction ratione materiae and personae of commercial courts in Rwanda is perplexing. The Law No. 06/2012/OL of 14/09/2012 determining the organization, functioning and jurisdiction of commercial courts which repealed Law No. 59/2007 of 16/12/2007, neither does it define a commercial activity nor does it define a trader. Unlike French commercial code, commercial activities are not enumerated in Rwandan commercial laws. In the wording of the article 2 of the aforementioned law, it is stated as follows:

"For the purpose of this Organic Law, "commercial matters" shall mean commercial, financial, fiscal and other related matters in connection with: 1.disputes arising from commercial contracts or commercial activities between individuals or business entities, "'35

It is important to know what a commercial activity is and who is a trader in determining the jurisdiction of commercial court. One may ask the following questions: Does any act posed by a trader amounts to commercial act? Can activities performed by non-trader be commercial? Are all traders registered in register of commerce? Since commercial activities are neither defined nor listed in the law and since the law does not define who is a trader, it is important to analyze jurisprudence to see how commercial courts in Rwanda deal with such issues.

\section{Case Law Analysis}

\footnotetext{
${ }^{34}$ ibid.

${ }^{35}$ See article 2(1) of the Organic Law of No. 06/2012/OL of 14/09/2012 determining the organization, functioning and jurisdiction of commercial courts, in $O . G$ No.45 of 05/11/2012.
} 
In AGRODEV case, AGRODEV SARL (represented by MUSHIMIRE) was a successful bidder for supplying woods in BUTARE prison. As AGRODEV SARL had no money, it asked RUDAHINYUKA to supply the woods on its behalf and the latter did it. However, AGRODEV SARL failed to pay RUDAHINYUKA for the completion of the agreed work. The latter sued AGRODEV SARL in commercial court of Nyarugenge which ruled in favour of the plaintiff. The decision was appealed against in Commercial High Court.

In Commercial High Court, the issue to be examined was to know whether RUDAHINYUKA was competent to sue in commercial courts. The court concluded that RUDAHINYUKA was competent since he was engaged in commercial activities by supplying woods to BUTARE prison. A person may perform a commercial activity without necessarily being a trader because the laws differentiate trader and commercial activity. ${ }^{36}$ The court explained that act of supplying woods amounted to commercial activity. The court said that a person cannot only be subject to commercial court because he/she is a trader but also the acts he/she performs if these acts amount to commercial activities. ${ }^{37}$

In the case NDARIHORANYE Vs FINABANK Ltd (hereinafter FINABANK case), commercial activities were ruled on. KANKWANZI Madeleine had taken a loan from BACAR (which later became FINABANK) to construct a house. KANKWANZI however, failed to pay the debt and BACAR sued her in Primary Court of Kigali. In the execution of the judgment, the house was auctioned because it was mortgaged and BACAR gained the possession. Later on, BACAR auctioned it and NDARIHORANYE became the new owner.

KANKWANZI sued BACAR in commercial court of Nyarugenge requesting the court to quash the auction and sucessfully, the court ruled in her favour. This decision was appealed against by NDARIHORANYE in Commercial Court of Nyarugenge but due to big value of claim, the court declared itself incompetent.

\footnotetext{
${ }^{36}$ Commercial High Court, Kigali 29/07/2011, AGRODEV Sarl v. R.V, Judgment No. R.COM A 0361/10/HCC (AGRODEV Sarl Case).

${ }^{37}$ ibid.
} 
The claim was referred in Commercial High Court which rejected it because of time limit for appeal. NDARIHORANYE sued FINABANK in the Commercial High Court requesting to force it to execute the mortgage on the house that was sold to him and the court said that the sale contract between BACAR and NDARIHORANYE was a civil sale. Therefore, conflicts arising from that contract had to go in ordinary courts. NDARIHORANYE seized the Supreme Court saying that the Commercial High Court disowned itself the competence whereas the case was commercial and the case was admitted.

The Supreme Court analysed whether the contract of sale between FINABANK and NDARIHORANYE was commercial. NDARIHORANYE claimed that Commercial High court, violated the article 3 al.3, which states that "commercial matters" shall mean commercial, financial, fiscal and other related matters in connection with: 1 . disputes arising from commercial contracts or commercial activities between individuals or business entities". ${ }^{38}$

NDARIHORANYE added that FINABANK bought the house and resold it to NDARIHORANYE in order to get back its money in business which made that sale a commercial sale. He added that the sale of mortgaged house by FINABANK was a commercial activity. The big question was to know whether the sale of the house to NDARIHORANYE was among the commercial activities pursuant to the article 3 of the law mentioned above. The court, according to the doctrines, explained that in case of confusion pertaining to knowing whether an act performed is not commercial, the burden of proof shall lay on the shoulder of trader who is disproving the commerciality of his/her acts. The court added that a civil act may be commercial if it is attached to commercial act or if such an act is performed by a trader. ${ }^{39}$ The court held that although the activity of purchasing and resale of house is not a usual activity of FINABANK, the latter bought that

\footnotetext{
${ }^{38}$ Article 3 (3) of the Organic Law No.59/2007 of 16/12/2007 establishing the commercial courts and determining their organization, functioning and jurisdiction.

${ }^{39}$ Kigali 22/02/2013, N. J.B v. FINA BANK Ltd, Judgment No. RCOM A 0122/11/CS ( FINABANK Case).
} 
house through public auction and the house was mortgaged on. Therefore, by reselling the house FINABANK wanted to bring back its money into business not necessarily that it could be written in its business activities. ${ }^{40}$

FINABANK failed to prove that act of resale of house was not a commercial activity. The court held that by selling the house to NDARIHORANYE, BACAR performed a commercial activity. Thus, the conflicts arising from that contract were subjected to commercial courts. Consequently, the Supreme Court referred the case back to the commercial court of NYARUGENGE. The court set standards which can be argued that registration in register of commerce is not the only indicator that a given person is engaged in commercial activity. The alleged non-trader must prove that his/her activity is not commercial.

\section{Conclusion}

Jurisdiction ratione personae and jurisdiction ratione materiae are important elements to ascertain the court competence to adjudicate commercial matters. Normally, the courts competences are enumerated in the law establishing it, its functioning and its jurisdiction. When this competence is not clearly enshrined in the law, it makes it hard to ascertain the jurisdiction which is the case in Rwandan commercial courts. This research shows that French commercial code and Rwandan laws relating to commercial courts as discussed earlier, have failed to define trader and commercial activities. This shortcoming poses ambiguity as to the jurisdiction ratione personae and jurisdiction ratione materiae of commercial courts.

Unlike Rwandan laws relating to commercial courts, French commercial code enumerates activities which are deemed commercial. However, judges have attempted to get rid of this confusions of knowing whether a given posed act is commercial activity or not. For example, in France the concern was to know whether an act of driving a taxi and gaining profit from it constituted a commercial activity. This puzzlement was removed in the case CITADINI vs. FELLEREAU

${ }^{40}$ ibid. 
and the case FREUDENRICH vs. JENOT.

In Rwanda, AGRODEV case and FINABANK case have shed light especially in determining jurisdiction ratione materiae of Commercial Courts in terms of commercial activities. However, it remains big challenge to determine some commercial activities and the status of trader. Therefore, this study calls upon the legislature to enact a new law that defines what is meant by a commercial activity or at least enumerate activities amounting to commerciality and define who a trader is. This will not only help Commercial Courts in determining their competence but also will bring people to the awareness of their status and courts they are subjected to. Briefly, although commercial activities are neither defined nor listed in the Rwandan laws, courts in Rwanda have tried to deal with related matters, albeit it is not easy, judges look into other jurisdictions and use legal doctrines, legal writings and case laws to handle the issue. To this end, the author suggests that there should be a law clearly defining what a trader is and what a commercial act encompasses. The author also suggests that, in case the law does not define what a trader and commercial activity are, it should at least enumerate activities that amount to commerciality.

\section{Bibliography}

\section{Books}

B. J. Odoki, 'The Relevancy of Commercial Courts to Modern Judiciary', A Case Study From Uganda: Chief Justies Forum Conference (Republic of Uganda 2010)<http://www.venice.coe.int/SACJF/2010_08_RSA_Johannesburg/ Uganda.pdf $>$.

L. Vogel, Commercial Code of France (legifrance 2006) <https://www.legifrance. gouv.fr/content/download/1951/13685/version/5/file/Code_32.p>.

P. Herzog dan M. Weser, Project on International Procedure : Civil Procedure in France (springer 2000).

P. Michel, Droit Commercial Commerçants et Fonds de Commerce, Concurrence, et Contrats de Commerce (2nd edn, Dalloz 200AD).

P.H. Collin, Dictionary of Law (4th edn, Bloomsbury Publishing 2004) $<$ http://www. academia.edu/14945138/Dictionary_of_Law_-_P_H._Collin_Bloomsbury_ 
Reference_4th_Edition_>.

UNCTAD, Dispute Settlement (Geneva 2003) <www.unctad.org>.

World Bank, 'Doing Business Report' (2009).

\section{Journals}

Robert Roberts III, 'Jurisdiction Ratione Materiae et Personae in Louisiana' (1952) 12 Louisiana Law Review <https://digitalcommons.law.lsu.edu/cgi/ viewcontent.cgi?article $=1933 \&$ context $=$ lalrev $>$.

\section{Web Site}

Cours Universiataire, 'LEA: Actes de Commerce' (Cours Universiataire) $<\mathrm{http}: / /$ www.cours-univ.fr/cours/licence/langues/licence-lea-droit-commercial-3. html $>$ accessed 6 November 2017.

Droit-Finance, 'Acte de Commmerce' (Droit-Finance) <http://droit-finances. commentcamarche.net/faq/23541-acte-de-commerce-definition> accessed 15 April 2011.

Dutch Civil Law, 'Jurisdiction' (dutchcivillaw) <http:/www.dutchcivillaw.com/ jurisdiction/nationaljuris.htm $>$ accessed 22 December 2017.

Lextenso, 'Activité Commercial Par Nature' (Lextenso) <athttps://www.lextenso. fr/lextenso/ud/urn:9782275 05 0294-91> accessed 14 April 2017.

US. Legal, 'Ratione Personae' (US. Legal, 2016) < http://definitions.uslegal.com/r/ ratione-personae $>$ accessed 22 December 2017.

US Legal, 'Commercial Activity' (US Legal, 2016) < http://definitions.uslegal. com/c/commercial-activity> accessed 24 December 2017.

\section{Legal Texts}

The Organic Law No. 06/2012/OL of 14/09/2012 determining the organization functioning and jurisdiction of commercial courts, (Republic of Rwanda Official Gazette No. 45 of 05/11/2012.

The Organic Law No. 59/2007 of 16/12/2007 establishing the commercial courts and determining their organization, functioning and jurisdiction.

Personal Information Protection and Electronic Documents Act (PIPEDA), $2003<$ https://www.priv.gc.ca/leg_c/interpretations_03_ca_e.asp $>$. 


\section{Case Laws}

CITADINI - chauffeur de taxi - contre FOLLEREAU frères - vendeurs de voiture (Arrêt de la cour d'Appel d'octobre 1937).

Arrêt de la cour de Cassation du 4 décembre 1968(Madame FREUDENRICH chauffeur de taxi-contre Madame JENOT - victime).

Commercial High Court, Kigali, 29/07/2011, AGRODEV Sarl v. R.V, Judgment no R.COM A 0361/10/HCC (AGRODEV Sarl Case).

Kigali22/02/2013, N. J.B v. FINA BANK Ltd, Judgment no RCOM A 0122/11/CS (FINABANK Case) Personal Information.

HOW TO CITE: Joel Niyobuhungiro, 'Perplexing Jurisdiction Ratione Personae And Materiae Of Rwandan Commercial Courts: Trader And Commercial Activity' (2018) 33 Yuridika. 